\begin{tabular}{l|l|l|}
\cline { 3 - 3 } CRITICAL & $\begin{array}{l}\text { Western Ghats } \\
\text { PARTNERSHIP FUND }\end{array}$ & $\begin{array}{l}\text { Special Series } \\
\text { Special Series }\end{array}$ \\
\hline
\end{tabular}

\title{
AMPHIBIAN COMMUNITIES IN THREE DIFFERENT COFFEE PLANTATION REGIMES IN THE WESTERN GHATS, INDIA
}

ISSN

Online 0974-7907

Print 0974-7893

OPEN ACCESS

\section{Shradha Rathod ${ }^{1} \&$ Pooja Rathod ${ }^{2}$}

${ }^{1}$ Durrell Institute of Conservation and Ecology University of Kent, Canterbury CT27NR, United Kingdom

${ }^{1}$ Current address: A/33, Suparshwanath Society, Market Yard Road, Pune, Maharashtra 411037, India

${ }^{2}$ National Centre for Biological Sciences, Tata Institute of Fundamental Research, Bengaluru, Karnataka 560065, India

${ }^{1}$ shradha.rathod@gmail.com (corresponding author), ${ }^{2}$ poojarathod90@gmail.com

Abstract: In the highly populated and diverse tropics, conservation in relatively pristine habitats is important but clearly inadequate for sustaining the earth's biological diversity. Agro-forestry systems such as shade-coffee plantations that incorporate arboreal vegetation are known to be more resilient for biodiversity conservation than other more drastic land transformations. We evaluated amphibian richness and diversity in 15 coffee plantations from three different regimes; organic coffee plantations, NPK coffee plantations and pesticide use coffee plantations in Kodagu District, Western Ghats, India. We treated five sacred groves as control region (CR) and sampled them using a combination of standardized visual and acoustic transect sampling. The sacred groves that were characterized by natural vegetation showed the highest richness and abundance of amphibians among the four regimes. In organic coffee plantations, overall abundance and richness of amphibians was significantly higher compared to NPK coffee plantations. On the other hand, amphibian richness and diversity in pesticide use coffee plantations were significantly lower compared to all other regimes. The results of the study clearly indicated that, the difference in habitat variables in coffee plantations and use of different treatments for pest control had a significant effect on the species richness and abundance of amphibians. This study highlights the great potential of sacred groves and organic coffee plantations as complementary habitat for the conservation of amphibians.

Keywords: Agro-forestry, conservation, organic, pesticides, sacred groves, shade coffee.
In a matrix of human-modified habitats showing multiple land use types, forest reserves are increasingly becoming isolated islands. These human modified landscapes are taking over the native forest and now form a significant amount of the earth's land surface (Bali et al. 2007). In the highly populated and diverse tropics, conservation in relatively pristine habitats is important but clearly inadequate for sustaining the earth's biological diversity (Janzen 1998; Daily et al. 2003). Agro forestry systems or plantation crops that incorporate arboreal vegetation are known to be more resilient for biodiversity conservation than other more drastic land transformations (Dolia et al. 2008). Therefore, prospects of conservation in structurally complex habitats like these should be given preference. Natural-shade coffee plantations are one of the classic examples of such a system (Perfecto et al. 1995, 1996; Moguel \& Toledo 1999; Rice \& Greenberg 2000; Kapoor 2007; Dolia et al. 2008).

\footnotetext{
DOI: http://dx.doi.org/10.11609/JoTT.03054.4404-13 | ZooBank: urn:Isid:zoobank.org:pub:D7423DD8-B6CB-421F-8B01-8BA4881329FF

Editor: Sanjay Molur, ZOO|WILD, Coimbatore, India.

Date of publication: 26 May 2013 (online \& print)
}

Manuscript details: Ms \# 03054 | Received 04 January 2012 | Final received 15 February 2013 | Finally accepted 06 May 2013

Citation: Rathod, S. \& P. Rathod (2013). Amphibian communities in three different coffee plantation regimes in the Western Ghats, India. Journal of Threatened Taxa 5(9): 4404-4413; http://dx.doi.org/10.11609/JoTT.o3054.4404-13

Copyright: (c) Rathod \& Rathod 2013. Creative Commons Attribution 3.0 Unported License. JoTT allows unrestricted use of this article in any medium, reproduction and distribution by providing adequate credit to the authors and the source of publication.

Funding: Durrell Institute of Conservation and Ecology, University of Kent, Canterbury, United Kingdom.

Competing Interest: None.

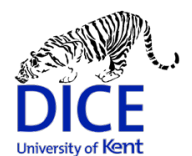

Acknowledgements: We thank Durrell Institute of Conservation and Ecology (DICE) for funding this project. We appreciate the logistical support provided by Drs. Sujata and Anurag Goel and several coffee estate owners who welcomed us to work in their plantations. We are grateful to A. Michael for his invaluable assistance during fieldwork. We thank Dr. R. Griffiths for providing valuable inputs, support and guidance throughout this project and Dr. J. Groombridge for help during analysis. We are grateful to R. Raghavan and A. Zambre for their critical comments, help, enthusiasm and belief in the project. We also thank S.D. Biju and S.P. Vijaykumar for their valuable comments.

The publication of this article is supported by the Critical Ecosystem Partnership Fund (CEPF), a joint initiative of l'Agence Française de Développement, Conservation International, the European Commission, the Global Environment Facility, the Government of Japan, the MacArthur Foundation and the World Bank. 
During the last century, the Western Ghats, a biodiversity hotspot (Myers et al. 2000) in peninsular India (Fig. 1) had undergone massive fragmentation due to multiple anthropogenic pressures. The southern Western Ghats were once characterized by vast expanses of tropical rainforest, but are now strewn with plantations of Tea Camellia sinensis, Coffee Coffea species, Rubber Hevea brasiliensis and Cardamom Elettaria cardamomum (Daniels et al. 1990; Chandran 1997). This has resulted in an approximately $40 \%$ loss of the natural vegetation and a four-fold increase in the number of forest fragments in the Western Ghats (Menon \& Bawa 1997). Coffee plantations covering an area of approximately $3,500 \mathrm{~km}$ are one of the major competitors for land in the Western Ghats (Ninan \& Sathyapalan 2005). The effects of tropical forest fragmentation and the biodiversity value of shadegrown coffee have been explored for various taxa such as mammals, plants, birds (Turner 1996; Perfecto et al. 1996, 2003) and insects (Perfecto \& Vandermeer 2002). Studies on the effects of coffee agro-ecosystems on amphibians are limited, and have been mainly restricted to inventories in Central and South America (Pineda \& Halffler 2004; Pineda et al. 2005). There has been a paucity of ecological research on amphibians, which is surprising given the fact that they are diverse and abundant, easily sampled and functionally significant. The ways in which they interact with their biotic and abiotic environment can reflect ecological changes (Noss
1990; Hill 1995) and therefore this group is promoted as a strong bioindicator of environmental stress (Carey \& Bryant 1995; Welsh \& Ollivier 1998; Blaustein et al. 2003).

Coffee was introduced in India in the 1740 s and since then it has been grown extensively by replacing the large native patches of wet-evergreen, mid elevation and moist deciduous forests in the southern Western Ghats which have been known to harbour extremely diverse endemic amphibian fauna (Daniels 1992; Das et al. 2006). In contrast to the clear felling followed by plantations of monoculture coffee in Central and South America, plantations of coffee and cardamom in the Western Ghats involve clearing of only the undergrowth leaving most of the native trees (canopy cover) intact. However, in recent years these native trees are gradually being replaced by the exotic, fast growing Silver Oak Grevillea robusta for economic benefits (S. Biju pers. comm. June 2012). This conversion from traditional to modern coffee cultivation has been considered a significant driver of biodiversity loss (Rappole et al. 2003).

Shade-coffee plantations in the southern Western Ghats fall under three different regimes:

(a) Organic coffee plantations (OCP's) follow standards and techniques that prohibit the use of herbicides, fertilizers and pesticides. This practice manifests the protection of crops against diseases at an ecological level by stimulating the natural defences

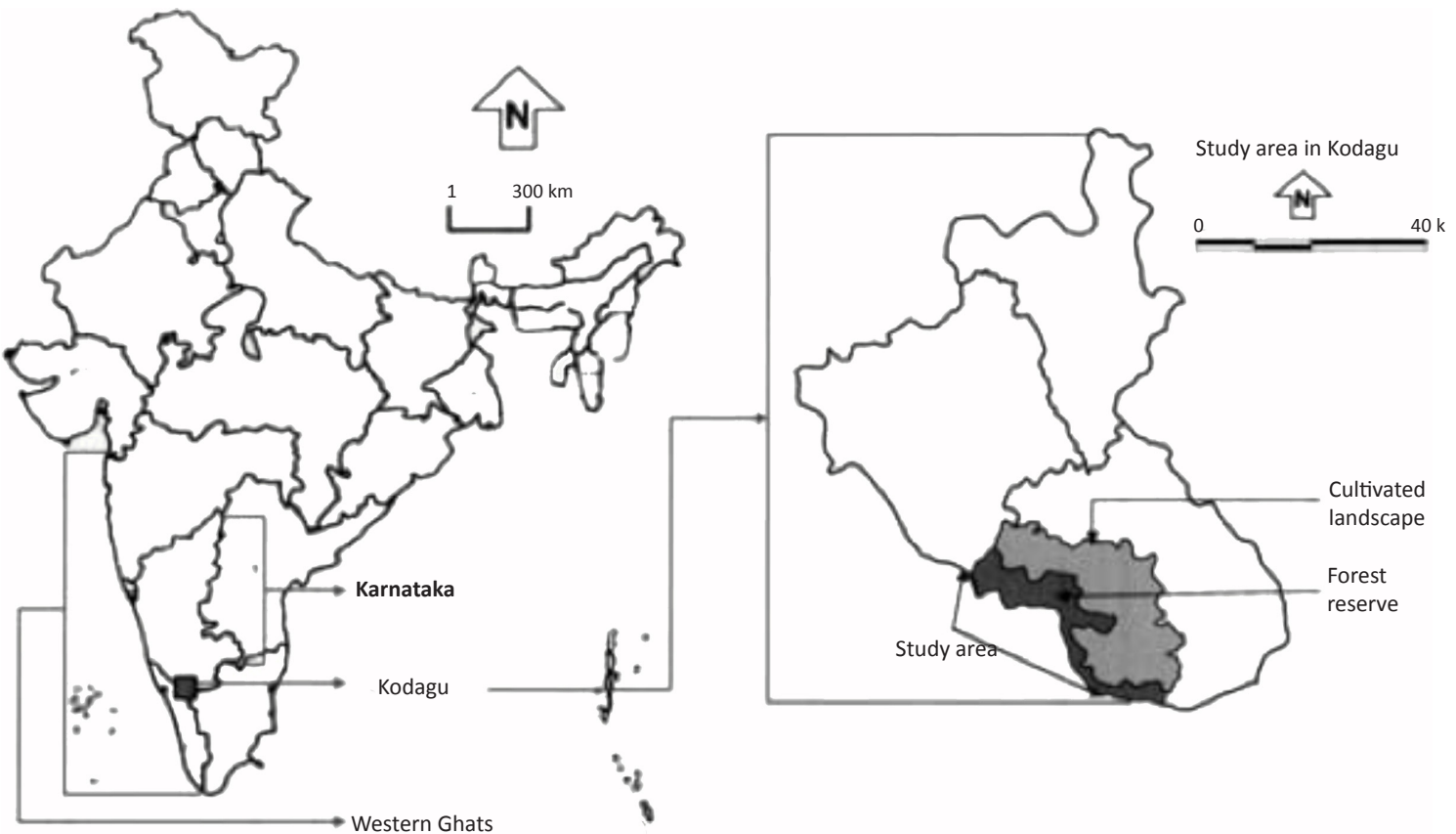

Image 1. The study area in Kodagu District, Karnataka. (Map adapted from Bhagwat et al. 2005). Sampling sites were located in the cultivated landscapes of the district. 
of plants themselves and through natural predation of pests wherein the native plant species are colonized by parasitic insects and play a significant role in controlling pest population. This practice also incorporates socially responsible activities such as environmental protection, recycling, and soil health.

(b) NPK coffee plantations (NCP's) use nitrogen (N), phosphorus $(\mathrm{P})$ and potassium $(\mathrm{K})$ that are commonly used in fertilizers. They also use fungicides like Bordeaux mixture, which is a combination of copper sulphate and hydrated lime.

(c) Pesticide using coffee plantations (PCP's) use pesticides such as chlorpyrifos, diazinon, disulfoton, methyl parathion, triadimefon, cypermethrin etc., for controlling major pests and pathogens. Locally these pesticides are sprayed no less than twice a year, in winter and post-monsoon.

(d) We sampled sacred groves as a control region (CR) for the current study. Sacred groves are patches of native forest that are interspersed among coffee plantations. These groves are patches of intact natural vegetation that are maintained by local communities where activities like hunting, logging or any kind of habitat modifications are strictly prohibited (Viswanath 2003).

Pesticide using coffee plantations make use of large amounts of pesticides to prevent damage from a multitude of pests (e.g., white stem borer, berry borer) and diseases (e.g., leaf rust and black rot) along with intensive shade lopping. Craves (2011) reports that, even though many chemicals that have been found to be harmful to the environment have been banned or are strictly regulated in the United States of America or Europe, they remain legal to be used in many less developed countries that grow coffee. These practices pose a serious threat to the existing amphibian fauna in the region (Gurushankara et al. 2007). Amphibians with their highly sensitive skin, bimodal life, complex life history and varied reproductive strategies (Lips 1998), tend to be highly susceptible to chemical contaminations (Pogorzeiska et al. 1982; Harris et al. 1998; Schiesari et al. 2007). The effects of environmental pollutants, particularly pesticides on amphibian communities have been of significant conservation interest for the past few decades. The responses of amphibian species can be strong but at the same time different to varying degree of landscape fragmentation and chemical pollutants like pesticides. For example, a preliminary investigation by Daniels (2003) suggests that despite the apprehensions about possible environmental contamination, tea estates tend to support a reasonably high diversity of amphibians in the southern Western Ghats. Hence, a thorough understanding of their responses to habitat modifications is indispensable for their long term conservation. The major aim of this study was to assess the effects of three different coffee plantation regimes on amphibian communities. The specific questions addressed were:

(a) Does the use of different regimes influence the species richness, relative abundance and community composition of amphibians in coffee plantations?

(b) Are some species affected more disproportionately than others?

(c) What other factors possibly influence amphibian assemblages in coffee plantations?

\section{Materials and Methods}

\section{Study site}

This study was conducted in June-July 2011 in Kodagu District $\left(11^{0} 56^{\prime}-12^{0} 52^{\prime} \mathrm{N} \& 75^{\circ} 22^{\prime}-76^{0} 11^{\prime} \mathrm{E}\right)$ of Karnataka State, in the Western Ghats, India. Elevation of Kodagu ranges from 900 to $1750 \mathrm{~m}$, and the area receives intense rainfall in the months of July and August. The annual rainfall ranges from 1500-4500 $\mathrm{mm}$ and is highly variable due to the topography of the region. Temperature ranges from $11-28{ }^{\circ} \mathrm{C}$. During the sampling period, monsoon had already set in and there was heavy rainfall throughout the study. Data was collected from coffee plantations and sacred groves that are spread across Kodagu District. Coffee was intercropped with Cardamom Elettaria cardomomum, Vanilla Vanilla planifolia and Pepper (Piper species). Shade-grown coffee plantations occupy approximately $60 \%$ of the landscape in Kodagu (Bhagwat et al. 2005). Ficus glomerata, Artocarpus integrifolia, Erythrina lithosperma and Albizia lebbeck are some native tree species commonly used as shade for coffee. However, these native species are being increasingly replaced by Silver Oak (S. Goel pers. comm. July 2011). We selected 15 coffee plantations and five sacred groves as sampling units.

\section{Coffee plantations}

The coffee plantations ranged 30-200 acres in area and fell within altitudes ranging 800-1200 m. A quadrate of $80 \times 50 \mathrm{~m}$ was placed using a rope in each plantation in order to incorporate maximum microhabitats used by amphibians. A combination of visual encounter surveys (VES) and acoustic encounter surveys (AES) (Rödel \& Ernst 2004) were conducted within each quadrate in order to estimate amphibian species richness and 
species composition of the local assemblage. In order to avoid confounding effects due to edge, each quadrate was set at least $50-80 \mathrm{~m}$ from the edge. Each survey was carried out for a period of 120 minutes (excluding the time for identification), $1800-2000 \mathrm{hr}$ in order to estimate amphibian abundance per unit time.

\section{Sacred groves}

The vegetation in sacred groves was dense and predominantly moist-deciduous with tall trees that formed the canopy. This was unlike coffee plantations that are short and hence amphibians could be visually detected. To overcome this problem we used a combination of standardized visual (SVTS) and acoustic (SATS) transect sampling (Rödel \& Ernst 2004). A $100 \mathrm{~m}$ transect was surveyed in each sacred grove and amphibian calls within $5 \mathrm{~m}$ on either side of the transect were recorded in addition to the individuals visually encountered on the ground. Transects were walked

Table 1. GPS locations and regimes of the 15 coffee plantation sites.

\begin{tabular}{|c|l|c|l|}
\hline Estate No. & Estate Name & Regime & GPS Locations \\
\hline 1 & $\begin{array}{l}\text { Rainforest Retreat } \\
\text { Valley } 2\end{array}$ & OCP & $12^{\circ} 27^{\prime} 24^{\prime \prime} \mathrm{N} \& 75^{\circ} 43^{\prime} 48^{\prime \prime} \mathrm{E}$ \\
\hline 2 & $\begin{array}{l}\text { Rainforest Retreat } \\
\text { Valley } 4\end{array}$ & OCP & $12^{\circ} 27^{\prime} 34^{\prime \prime} \mathrm{N} \& 75^{\circ} 44^{\prime} 24^{\prime \prime} \mathrm{E}$ \\
\hline 3 & Benny Estate & OCP & $12^{\circ} 28^{\prime} 31^{\prime \prime} \mathrm{N} \& 75^{\circ} 45^{\prime} 36^{\prime \prime} \mathrm{E}$ \\
\hline 4 & Emanual Estate & OCP & $12^{\circ} 27^{\prime} 30^{\prime \prime} \mathrm{N} \& 75^{\circ} 49^{\prime} 7^{\prime \prime} \mathrm{E}$ \\
\hline 5 & Ludwik Estate & OCP & $12^{\circ} 26^{\prime} 8^{\prime \prime} \mathrm{N} \& 75^{\circ} 44^{\prime} 46^{\prime \prime} \mathrm{E}$ \\
\hline 6 & Sandel Kad Estate & $\mathrm{PCP}$ & $12^{\circ} 26^{\prime} 4^{\prime \prime} \mathrm{N} \& 75^{\circ} 45^{\prime} 13^{\prime \prime} \mathrm{E}$ \\
\hline 7 & School Estate & $\mathrm{PCP}$ & $12^{\circ} 25^{\prime} 59^{\prime \prime} \mathrm{N} \& 75^{\circ} 45^{\prime} 36^{\prime \prime} \mathrm{E}$ \\
\hline 8 & Rajeev Estate & $\mathrm{PCP}$ & $12^{\circ} 25^{\prime} 21^{\prime \prime} \mathrm{N} \& 75^{\circ} 49^{\prime} 29^{\prime \prime} \mathrm{E}$ \\
\hline 9 & Jyoti Estate & $\mathrm{PCP}$ & $12^{\circ} 29^{\prime} 49^{\prime \prime} \mathrm{N} \& 75^{\circ} 44^{\prime} 41^{\prime \prime} \mathrm{E}$ \\
\hline 10 & Vrindivan Estate & $\mathrm{PCP}$ & $12^{\circ} 29^{\prime} 16^{\prime \prime} \mathrm{N} \& 75^{\circ} 45^{\prime} 8^{\prime \prime} \mathrm{E}$ \\
\hline 11 & Utthapa Estate & $\mathrm{NCP}$ & $12^{\circ} 29^{\prime} 58^{\prime \prime} \mathrm{N} \& 75^{\circ} 44^{\prime} 14^{\prime \prime} \mathrm{E}$ \\
\hline 12 & Kavery Estate & $\mathrm{NCP}$ & $12^{\circ} 28^{\prime} 20^{\prime \prime} \mathrm{N} \& 75^{\circ} 46^{\prime} 18^{\prime \prime} \mathrm{E}$ \\
\hline 13 & Quality Estate & $\mathrm{NCP}$ & $12^{\circ} 27^{\prime} 1^{\prime \prime} \mathrm{N} \& 75^{\circ} 41^{\prime} 20^{\prime \prime} \mathrm{E}$ \\
\hline 14 & Shivappa Estate & $\mathrm{NCP}$ & $12^{\circ} 28^{\prime} 23^{\prime \prime} \mathrm{N} \& 75^{\circ} 42^{\prime} 18^{\prime \prime} \mathrm{E}$ \\
\hline 15 & Muthanna Estate & $\mathrm{NCP}$ & $12^{\circ} 27^{\prime} 2^{\prime \prime} \mathrm{N} \& 75^{\circ} 43^{\prime} 37^{\prime \prime} \mathrm{E}$ \\
\hline
\end{tabular}

Table 2. GPS locations of the five sacred groves (control regime)

\begin{tabular}{|c|l|}
\hline Sacred grove no. & GPS location \\
\hline 1 & $12^{\circ} 25^{\prime} 32^{\prime \prime} \mathrm{N} \& 75^{\circ} 42^{\prime} 47^{\prime \prime} \mathrm{E}$ \\
\hline 2 & $12^{\circ} 25^{\prime} 28^{\prime \prime} \mathrm{N} \& 75^{\circ} 41^{\prime} 50^{\prime \prime} \mathrm{E}$ \\
\hline 3 & $12^{\circ} 27^{\prime} 59^{\prime \prime} \mathrm{N} \& 75^{\circ} 44^{\prime} 35^{\prime \prime} \mathrm{E}$ \\
\hline 4 & $12^{\circ} 23^{\prime} 34^{\prime \prime} \mathrm{N} \& 75^{\circ} 45^{\prime} 24^{\prime \prime} \mathrm{E}$ \\
\hline 5 & $12^{\circ} 25^{\prime} 20^{\prime \prime} \mathrm{N} \& 75^{\circ} 46^{\prime} 19^{\prime \prime} \mathrm{E}$ \\
\hline
\end{tabular}

between 1800 and $2000 \mathrm{hr}$ with sampling duration of 120 minutes to estimate amphibian abundance per unit time. All observations were made by two observers assisted by a field assistant. All micro-habitats such as foliage, branches, tree barks, twigs, leaves were carefully scanned. Leaf litter was thoroughly searched and occasionally shifted and amphibians dispatched from the litter were included in the sample.

\section{Taxonomy}

Amphibians were identified to the genus and species levels using identification keys provided in Daniel (2002), Biju \& Bossuyt (2005, 2006, 2009), Biju et al. (2011), Kuramoto et al. (2007) and Zachariah et al. (2010, 2011). Individual amphibians that could not be identified on site were caught, identified and subsequently released in the same quadrat.

\section{Microclimatic variables}

We measured maximum and minimum air temperature and humidity at the start of sampling each quadrate with a digital $\mathrm{max} / \mathrm{min}$ thermo-hygrometer. Location of each sampling unit (quadrate in each plantation) was recorded using a GPS (Garmin eTrex Vista HCx) (Tables 1 \& 2).

\section{Analysis}

Exploratory data analysis was performed using SPSS version 18.0 (SPSS 2009). Parametric statistical tests such as one-way analysis of variance (ANOVA) were used to see if species richness and abundance differ significantly across the four regimes. Diversity of amphibian assemblages was measured with the Shannon-Wiener index $(H)$ and its respective evenness $\left(E_{H}\right)$. Using ANOVA, we compared the calculated $\mathrm{H}$-values and $\mathrm{E}_{\mathrm{H}}$-values for the four regimes.

\section{Results}

A total of 594 amphibians belonging to 22 species were recorded during this study. We recorded 377 amphibians using a combination of VES and AES in 30 hours of quadrate sampling in 15 coffee plantations and 217 amphibians using a combination of SVTS and SATS in 10 hours of transect sampling in five sacred groves. Out of these, 19 species were recorded from organic coffee plantations, 15 species from NPK coffee plantations, 13 from pesticide using coffee plantations and 15 species from sacred groves (Table 3 ). 

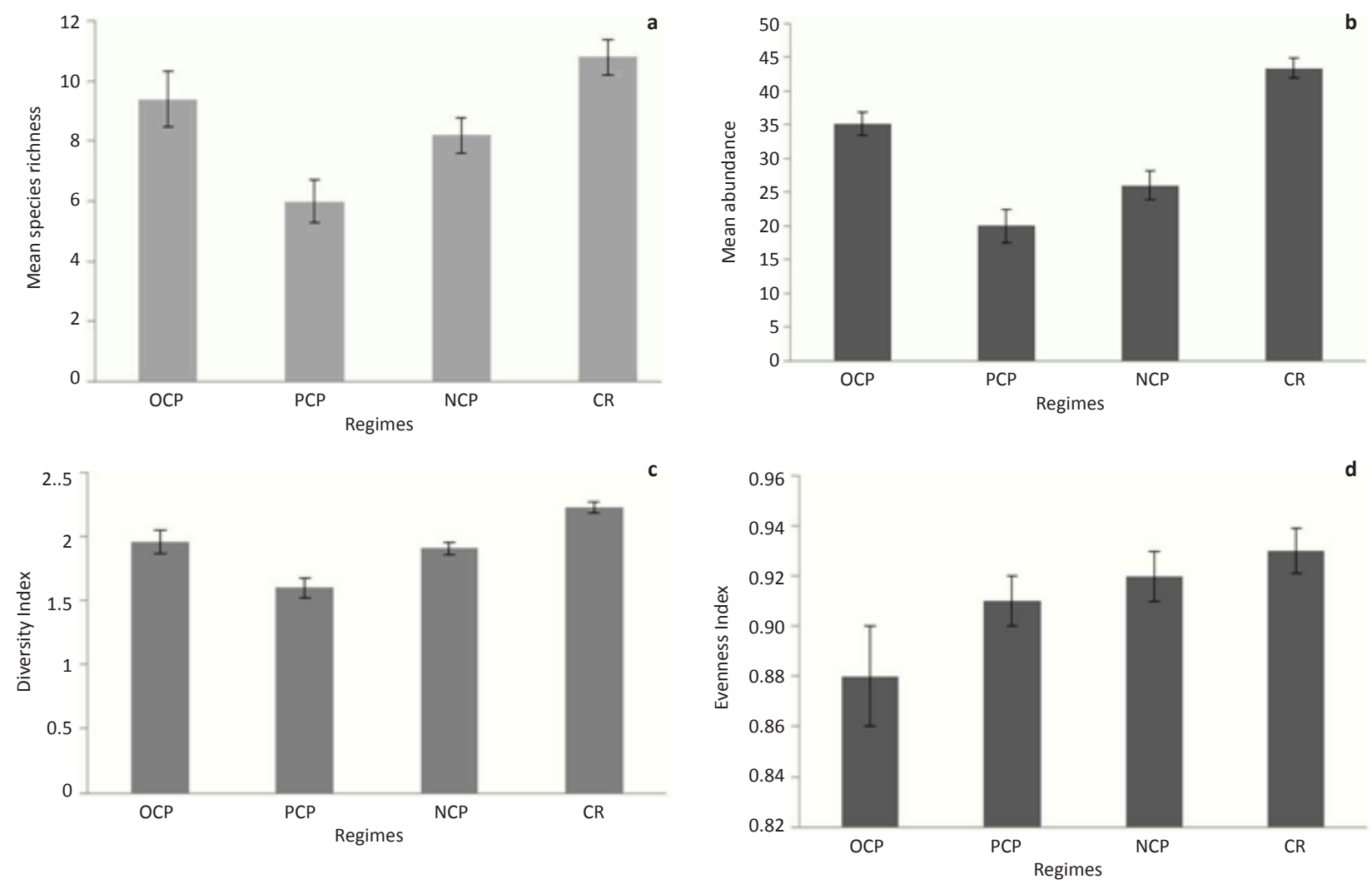

Figure 2a-d. a - Mean species richness of amphibians across sites; b - Mean abundance across sites; c - Diversity index across sites; d - Evenness index across sites.

\section{Amphibian species richness and abundance}

Amphibian species richness was significantly different in organic coffee plantations and NPK coffee plantations, and the same way between organic coffee plantations and sacred groves $\left(\mathrm{F}_{3,16}=8.105, \mathrm{P}<0.002\right)$ (Fig. 2a). Moreover, abundance of amphibians was influenced by the regimes as there was a significant difference in the values between plantations $\left(F_{3,16}=26.443, P<0.001\right)$ (Fig. $2 b$ and Fig. 3).

\section{Shannon-Wiener Diversity Index}

Figure 2c represents Shannon's diversity index $(H)$. The results indicate that there is a significant difference in the diversity across the four regimes $\left(F_{3,16}=12.165\right.$, $P<0.001)$. The results of Shannon's evenness index $\left(E_{H}\right)$ was statistically insignificant $\left(F_{3,16}=1.957, P<0.161\right)$ indicating that individuals in the community are distributed equitably among the species across the four regimes (Fig. 2d).

\section{Discussion}

The current study was an attempt to understand species community level patterns of amphibians within three different coffee growing practices. The results of this study clearly indicates that the difference in habitat variables in coffee plantations and use of different treatments for pest control had a significant effect on the species richness and abundance of amphibians. Species richness and abundance was highest in organic coffee plantations and decreased in NPK and pesticide using plantations. We observed a high diversity of native rainforest trees in organic coffee plantations. NPK coffee plantations on the other hand, consist of mixed canopy of native and exotic trees such as Maesopsis eminii, Bischofia javanica, Spathodes campanulata, Erythrina lithosperma, Ailanthus integrifolia and Ficus spp. However, pesticides using coffee plantations were dominated by exotic monoculture of silver oak trees resulting in decreased canopy cover. Decreasing canopy cover resulting in higher temperatures, decreasing atmospheric humidity and increasing wind velocity (Saunders et al. 1991; Murcia 1995; Pineda \& Halffter 
Table 3. Presence-absence data for all the recorded species across three different coffee plantation regimes and control region (Sacred groves).

\begin{tabular}{|c|c|c|c|c|c|c|}
\hline & Species & $\begin{array}{l}\text { IUCN Red List } \\
\text { status }\end{array}$ & OCP & PCP & NCP & $\mathrm{CF}$ \\
\hline & \multicolumn{6}{|l|}{ Bufonidae } \\
\hline 1 & $\begin{array}{l}\text { Duttaphrynus } \\
\text { melanostictus }\end{array}$ & Least Concern & 1 & 1 & 1 & 1 \\
\hline 2 & $\begin{array}{l}\text { Duttaphrynus } \\
\text { penninsularis * }\end{array}$ & $\begin{array}{l}\text { Critically } \\
\text { Endangered }\end{array}$ & 1 & 0 & 0 & 0 \\
\hline \multirow[t]{2}{*}{3} & $\begin{array}{l}\text { Duttaphrynus } \\
\text { stomaticus }\end{array}$ & Least Concern & 0 & 0 & 1 & 0 \\
\hline & \multicolumn{6}{|l|}{ Dicroglossidae } \\
\hline 4 & $\begin{array}{l}\text { Hoplobatrachus } \\
\text { tigrinus }\end{array}$ & Least Concern & 1 & 0 & 0 & 0 \\
\hline \multirow[t]{2}{*}{5} & Zakerana sp. & Data Deficient & 1 & 1 & 1 & 1 \\
\hline & \multicolumn{6}{|l|}{ Microhylidae } \\
\hline 6 & Microhyla ornata & Least Concern & 1 & 1 & 1 & 1 \\
\hline \multirow[t]{2}{*}{7} & $\begin{array}{l}\text { Ramanella } \\
\text { triangularis * }\end{array}$ & Vulnerable & 1 & 0 & 1 & 1 \\
\hline & \multicolumn{6}{|l|}{ Nyctibatrachidae } \\
\hline \multirow[t]{2}{*}{8} & $\begin{array}{l}\text { Nyctibatrachus } \\
\text { kemphloyensis }\end{array}$ & Data Deficient & 1 & 0 & 1 & 0 \\
\hline & \multicolumn{6}{|l|}{ Ranidae } \\
\hline 9 & $\begin{array}{l}\text { Clinotarsus } \\
\text { curtipes * }\end{array}$ & $\begin{array}{l}\text { Near } \\
\text { Threatened }\end{array}$ & 1 & 1 & 1 & 1 \\
\hline \multirow[t]{2}{*}{10} & $\begin{array}{l}\text { Hylarana } \\
\text { temporalis }\end{array}$ & $\begin{array}{l}\text { Near } \\
\text { Threatened }\end{array}$ & 1 & 1 & 1 & 1 \\
\hline & \multicolumn{6}{|l|}{ Rhacophoridae } \\
\hline 11 & $\begin{array}{l}\text { Polypedates } \\
\text { maculatus }\end{array}$ & Least Concern & 1 & 1 & 1 & 1 \\
\hline 12 & $\begin{array}{l}\text { Polypedates } \\
\text { occidentalis * } \\
\text { (Image } 1 \text { ) }\end{array}$ & Data Deficient & 1 & 0 & 0 & 1 \\
\hline 13 & $\begin{array}{l}\text { Raorchestes } \\
\text { acroparallagi * } \\
\text { (Image 2) }\end{array}$ & Data Deficient & 1 & 1 & 1 & 1 \\
\hline 14 & Raorchestes anili * & Least Concern & 1 & 0 & 0 & 0 \\
\hline 15 & $\begin{array}{l}\text { Raorchestes } \\
\text { charius * }\end{array}$ & Endangered & 1 & 1 & 1 & 1 \\
\hline 16 & $\begin{array}{l}\text { Raorchestes } \\
\text { glandulosis * }\end{array}$ & Vulnerable & 0 & 1 & 1 & 0 \\
\hline 17 & $\begin{array}{l}\text { Raorchestes } \\
\text { luteolus * } \\
\text { (Image 3) }\end{array}$ & Vulnerable & 1 & 1 & 1 & 1 \\
\hline 18 & $\begin{array}{l}\text { Raorchestes } \\
\text { ponmudi }{ }^{*}\end{array}$ & $\begin{array}{l}\text { Critically } \\
\text { Endangered }\end{array}$ & 0 & 1 & 1 & 1 \\
\hline 19 & $\begin{array}{l}\text { Raorchestes } \\
\text { tuberohumerous * }\end{array}$ & Data Deficient & 1 & 1 & 0 & 1 \\
\hline 20 & $\begin{array}{l}\text { Raorchestes } \\
\text { wynaadensis* }\end{array}$ & Data Deficient & 1 & 1 & 1 & 1 \\
\hline 21 & $\begin{array}{l}\text { Rhacophorus } \\
\text { lateralis* } \\
\text { (Image } 4)\end{array}$ & Endangered & 1 & 0 & 0 & 0 \\
\hline 22 & $\begin{array}{l}\text { Rhacophorus } \\
\text { malabaricus * }\end{array}$ & Least Concern & 1 & 0 & 0 & 1 \\
\hline
\end{tabular}

* - Endemic to Western Ghats; 1 - present; 0 - absent.

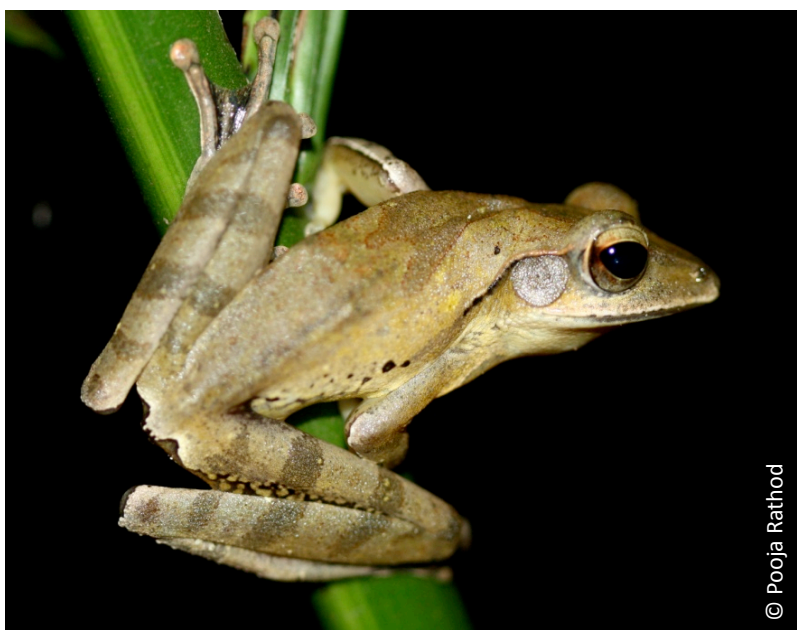

Image 1. Polypedates occidentalis from Kodagu, Western Ghats.

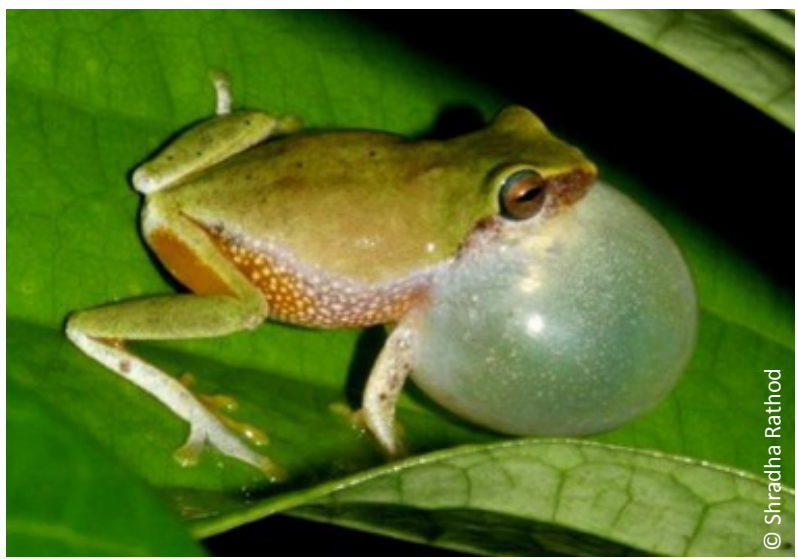

Image 2. Raorchestes acroparallagi from Kodagu, Western Ghats.

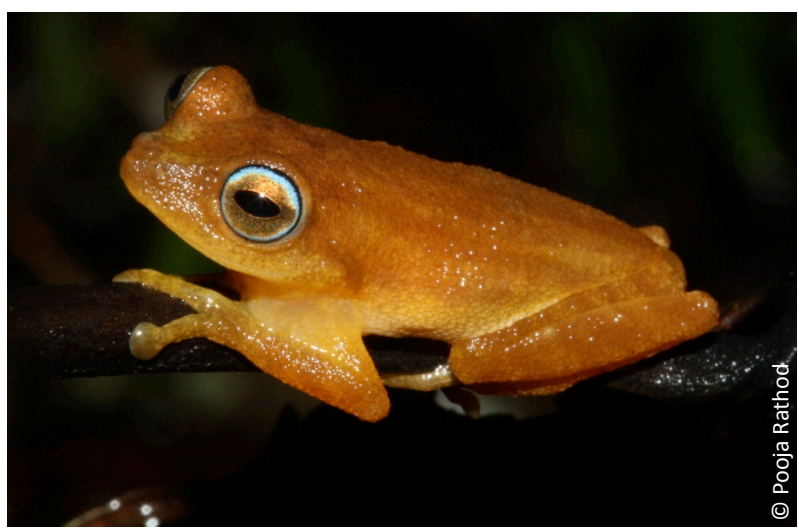

Image 3. Raorchestes luteolus from Kodagu, Western Ghats. 

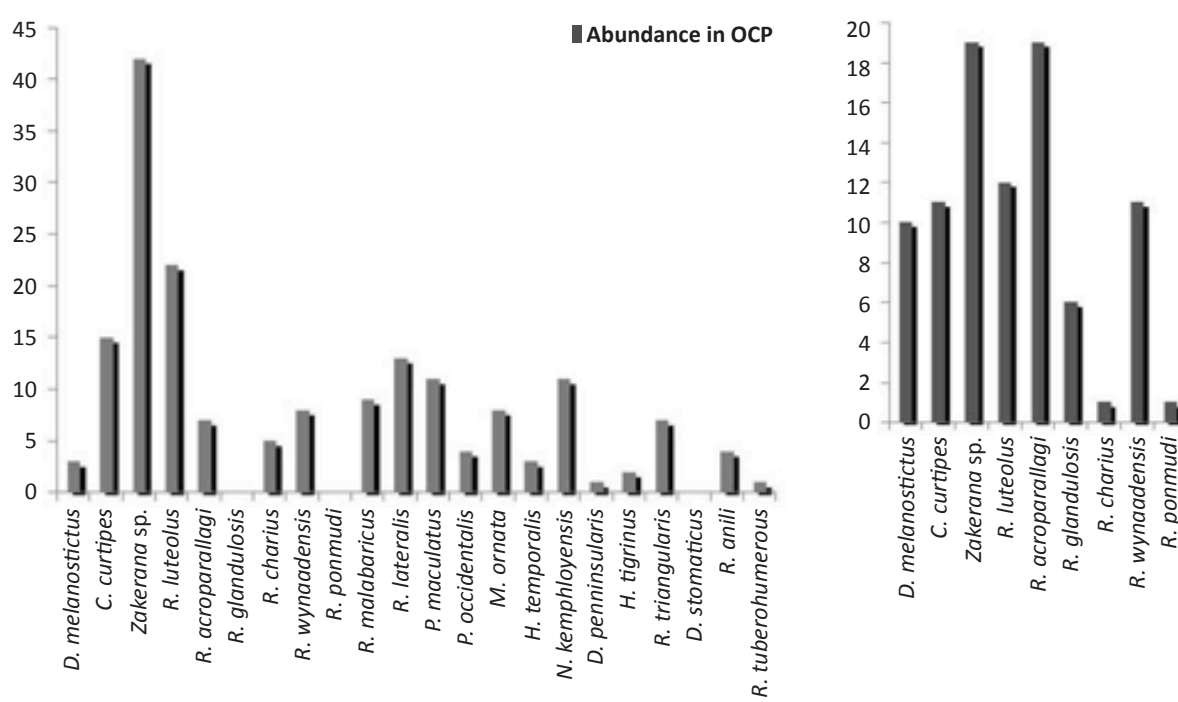

Abundance in NCP
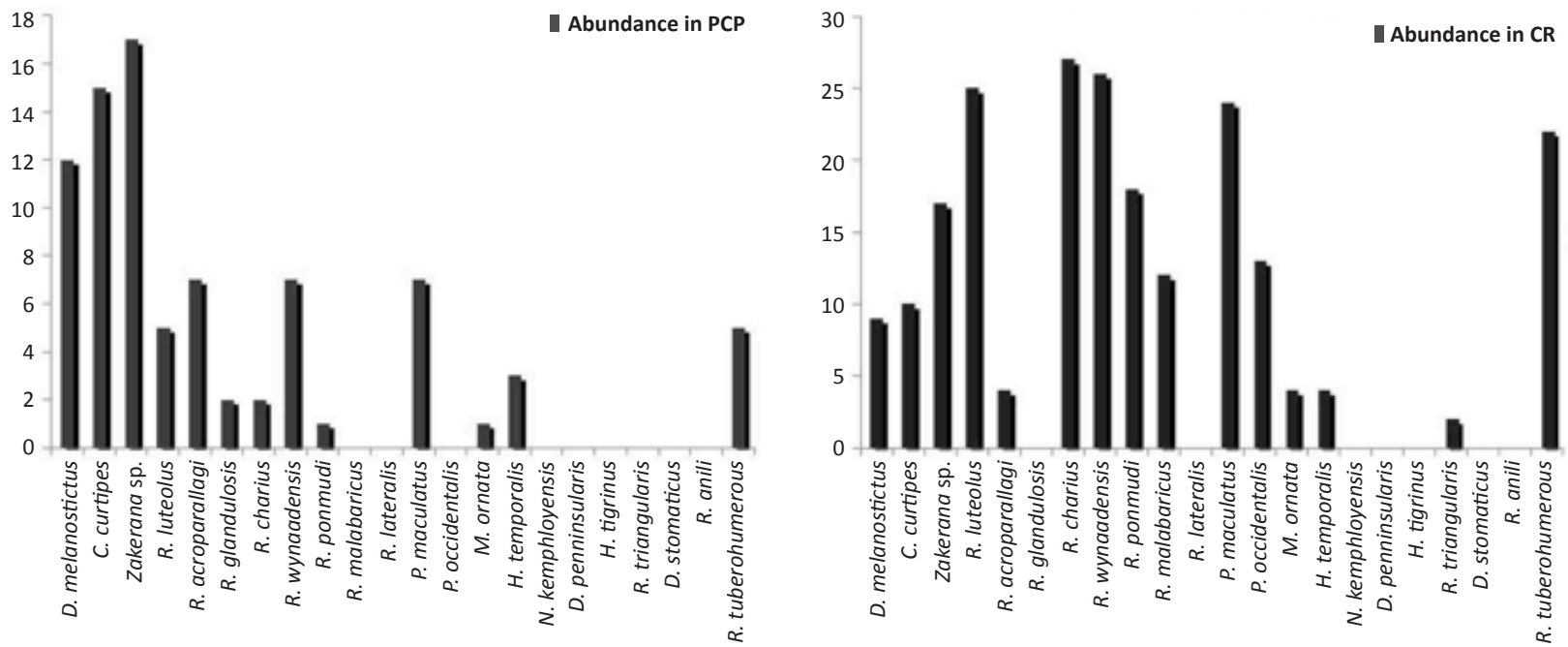

Figure 3. Abundance of amphibians across three different coffee plantation regimes and control region.

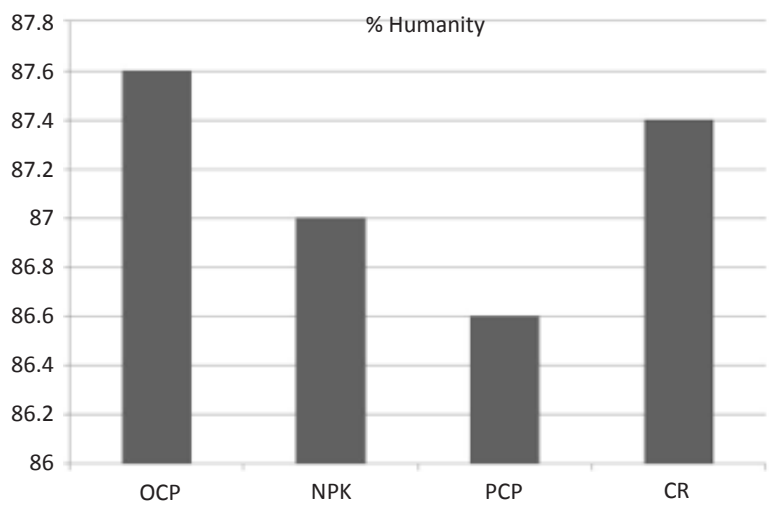

Figure 4. Abundance of amphibians across three different coffee plantation regimes and control region.

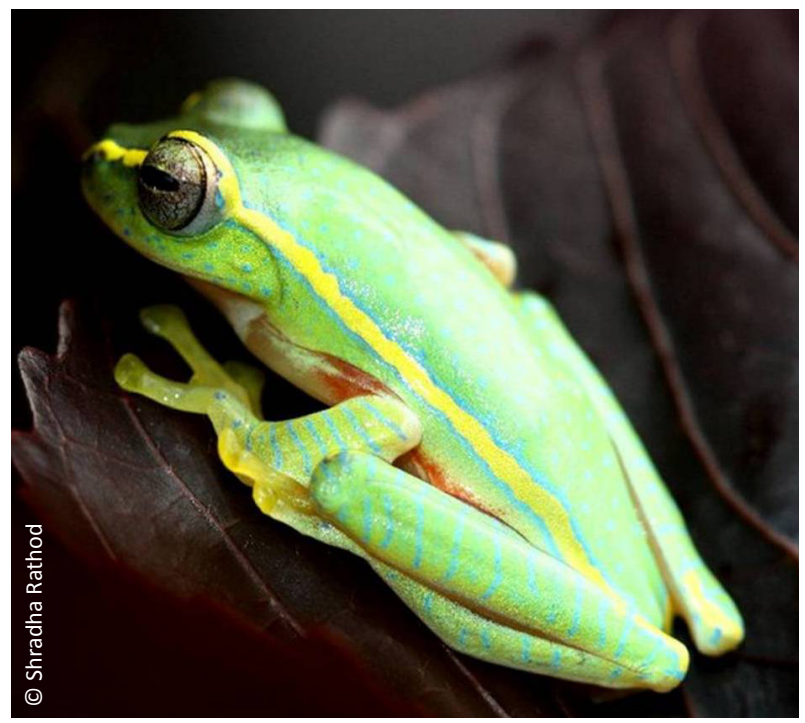

Image 4. Rhacophorus Iateralis from Kodagu, Western Ghats. 
2004) which could account for the decreased species richness and abundance. The humidity levels recorded during the current study show a decreasing trend as we go from OCP to NCP and PCP. Humidity levels in OCP and CR were almost comparable. However, the decline is not very pronounced; hence it will be difficult to draw any conclusions (Fig. 4).

Species composition often varies across different land use types and regimes and species that require specific ecological conditions that are not available in modified land uses may be more affected than others (Waltert et al. 2004). Presence of aquatic habitats plays a key role in the maintenance of particular amphibian species (Neckel-Olivieira \& Gascon 2006). In the present study, the complete absence of two species, Rhacophorus malabaricus and $R$. lateralis from NPK coffee plantations and pesticide using coffee plantations can be due to an absence of aquatic habitats in these two coffee regimes. Hillers et al. (2008) reports that a more open canopy can enhance higher temperatures and increased evaporation and may reduce persistence of aquatic habitats. The organic coffee plantations sites had natural as well as man-made aquatic pools, while sacred groves had natural water bodies, which provided breeding sites for certain species within the family Rhacophoridae. Generalist species like the Indian Bull Frog Hoplobatrachus tigerinus (Daniels 2002) were also completely absent from NPK coffee plantations and pesticide using coffee plantation regimes, which could again be a consequence of unavailability of aquatic breeding sites.

Nyctibatrachus sp. and Ramanella sp. that belong to the genera of forest dependent species endemic to the Western Ghats (Aravind \& Gururaja 2011) along with other terrestrial amphibians (Table 3 ) were completely absent from pesticide using coffee plantations. These species could be most affected as planters in this regime regularly use herbicides and practice manual de-weeding that causes disturbance to understory vegetation. These practices may have negatively affected terrestrial amphibians at various stages (eggs, juvenile, sub-adults and adults) potentially leading to reduced fitness and recruitment. Gurushankara et al. (2007) observed the highest incidence of morphological abnormalities in populations of frogs inhabiting coffee plantations and suspected chemical contamination (both fertilizer and pesticide) to be the cause. Absence of forest-dependent species of Nyctibatrachus sp. and Micrixalus sp. from coffee plantations have also been reported by Krishna et al. (2005) and Aravind \& Gururaja (2011). Zakerana sp. was highest in abundance across all three regimes.
According to Kuramoto et al. (2007), Zakerana are generalists that occur near still and stagnant water where they are known to breed. Such habitats were available throughout all coffee estates as the first order streams were partially swampy due to open canopy and understory vegetation.

While understanding the impact of coffee on species from the genus Raorchestes commonly known as bush frogs, it would not be possible to treat species richness and life-history strategies separately. For instance, species from this genus have direct development (Biju 2003) and thus provide little protection to the eggs, when coffee is sprayed with pesticides. However, these species have been able to survive in all three regimes and sacred groves. Although it cannot be entirely explained, survival of the bush frog may partly be attributed to their breeding period. Breeding takes place during the wettest part of the year, whereas pesticides are sprayed during post-monsoon and winter. As the bush frogs stay dormant during these times of the year, probably under leaf litter and barks, when most of the foliar applications of pesticides take place, they may barely be exposed to pesticides directly.

Despite some clear patterns, the present study had several limitations. It is representative only of the southwest monsoon season as it was carried out during June and July. Visibility also varied across the three regimes, being highest in pesticide using coffee plantations, followed by NPK and organic coffee plantations, then sacred groves, suggesting that the higher richness and abundance in the latter may only be a conservative estimate. Due to a lack of accessibility, canopy species were completely omitted. Zakerana sp. could be identified only to the genus level hence, we cannot comment on its species richness across the coffee estates and sacred groves. A long-term study should be conducted in order to understand the variables that drive the resulting patterns of this study.

\section{Coffee plantations as habitats for amphibians}

This study nevertheless highlights the great potential of organic coffee plantations and sacred groves as complementary habitat for the conservation of amphibians. However, certain drawbacks of NPK coffee plantations and pesticide using coffee plantation regimes like certain habitat variables and use of fertilizers and pesticides, respectively, may prevent them from being an ideal habitat for amphibians. A study that compared morphological abnormalities in natural populations of frogs inhabiting agro-ecosystems of central Western Ghats showed that coffee plantations had the highest 
incidence of abnormality that could have resulted due to the use of large amounts of chemical fertilizers and pesticides (Gurushankara et al. 2007). Further studies that take into account pesticide use in coffee plantations may reveal additional factors that influence community structure attributes like richness and abundance of amphibians as well as their fitness in coffee plantations. Given the Indian scenario, creating more inviolate spaces in the Western Ghats is unlikely to win much support in the present economic and political context. This study coupled with other independent studies (Gray et al. 2004; Pineda et al. 2005; Bali et al. 2006; Kapoor 2007; Dolia et al. 2008) suggest that, promoting organic coffee plantation practices can have a greater positive impact on biodiversity conservation. It is important to consider that these coffee dominated landscapes might be the last refuge in modified landscapes for some highly endemic species. The present study forms a useful baseline for agriculturists, as the decisions they take can dramatically affect our biodiversity levels.

\section{REFERENCES}

Aravind, N.A. \& K.V. Gururaja (2011). Amphibians of the Western Ghats. Theme paper, Western Ghats Ecology Expert Panel, Ministry of Environment and Forests, India.

Bali, A., A. Kumar \& J. Krishnaswamy (2007). The mammalian communities in coffee plantations around a protected area in the Western Ghats, India. Biological Conservation 139: 93-102; http:// dx.doi.org/10.1016/j.biocon.2007.06.017

Bhagwat, S.A., C.G. Kushalappa, P.H. Williams \& N.D. Brown (2005). A landscape approach to biodiversity conservation of sacred groves in the Western Ghats of India. Conservation Biology 19: 1853-1862 http://dx.doi.org/10.1111/j.1523-1739.2005.00248.x

Biju. S.D. (2003). Reproductive mode in the shrub frog Philautus glandulosus (Jerdon, 1853) (Anura: Rhacophoridae). Current Science 84(3): 283-284.

Biju, S.D. \& F. Bossuyt (2005). New species of Philautus (Anura: Ranidae, Rhacophorinae) from Ponmudi Hill in the Western Ghats of India. Journal of Herpetology 39: 349-353; http://dx.doi. org/10.1670/133-04A.1

Biju, S.D. \& F. Bossuyt (2006). Two new species of Philautus (Anura, Ranidae, Rhacophorinae) from the Western Ghats, India. Amphibia Reptilia 27: 1-9; http://dx.doi.org/10.1163/156853806776051985

Biju, S.D. \& F. Bossuyt (2009). Systematics and phylogeny of Philautus Gistel, 1848 (Anura, Rhacophoridae) in the Western Ghats of India, with descriptions of 12 new species. Zoological Journal of the Linnean Society 155: 374-444; http://dx.doi.org/10.1111/j.10963642.2008.00466.x

Biju, S.D., I. van Bocxlaer, S. Mahony, K.P. Dinesh, C. Radhakrishnan, A. Zachariah, V. Giri \& F. Bossuyt (2011). A taxonomic review of the Night Frog genus Nyctibatrachus Boulenger, 1882 in the Western Ghats, India (Anura: Nyctibatrachidae) with description of twelve new species. Zootaxa 3029: 1-96.

Blaustein, A.R., J.M. Romansic, J.M. Kiesecker \& A.C. Hatch (2003). Ultraviolet radiation, toxic chemicals and amphibian population declines. Diversity and Distribution 9: 123-140; http://dx.doi. org/10.1046/j.1472-4642.2003.00015.x

Carey, C. \& C.J. Bryant (1995). Possible interrelations among environmental toxicants, amphibian development, and decline of amphibian populations. Environmental Health Perspectives 103: 13-17.

Chandran, M.D.S. (1997). On the ecological history of the Western Ghats. Current Science 73: 146-155.

Craves, J. (2011). Common pesticides-Coffee and conservation. http:// www.coffeehabitat.com/2006/12/pesticides_used_2/On-line version dated 1 August 2011

Daniels, R.J. (2003). Impact of tea cultivation on anurans in the Western Ghats. Current Science 85: 1415-1422.

Daily, G.C., G. Ceballos, J. Pacheco, G. Suzan \& A. Sanchez-Azofeifa (2003). Countryside biogeography of neotropical mammals: conservation opportunities in agricultural landscapes of Costa Rica. Conservation Biology 17: 1814-1826; http://dx.doi.org/10.1111/ j.1523-1739.2003.00298.x

Daniels, R.J.R., M. Hegde \& M. Gadgil (1990). Birds of the man-made ecosystems: the plantations. Animal Science 99: 79-89; http:// dx.doi.org/10.1007/BF03186376

Daniels, R.J.R. (1992). Geographical distribution patterns of amphibians in Western Ghats, India. Journal of Biogeography 19: 521-529.

Daniel, J.C. (2002). The Book of Indian Reptiles and Amphibians. Oxford University Press, India, 248pp.

Das, A., J. Krishnaswamy, K.S. Bawa, M.C. Kiran, V. Srinivas, N.S. Kumar \& K.U. Karanth (2006). Prioritization of conservation areas in Western Ghats, India. Biological Conservation 133: 16-31; http:// dx.doi.org/10.1016/j.biocon.2006.05.023

Dolia, J., M.S. Devy, N.A. Aravind \& A. Kumar (2008). Adult butterfly communities in coffee plantations around a protected area in the Western Ghats, India. Animal Conservation 26: 26-34; http://dx.doi. org/10.1111/j.1469-1795.2007.00143.x

Gurushankara, H.P., S.V. Krishnamurthy \& V. Vasudev (2007). Morphological abnormalities in natural populations of common frogs inhibiting agrosystems of central Western Ghats. Applied Herpetology 4: 39-45

Harris, M.L., C.A. Bishop, J. Struger, B. Ripley \& J.P. Bogart (1998). The functional integrity of northern Leopard Frog (Rana pipiens) and Green Frog (Rana clamitans) populations in Orchard wetlands. II. Effects of pesticides and eutrophic conditions on early life stage development. Environmental Toxicology and Chemistry 17: 13511363; http://dx.doi.org/10.1002/etc.5620170720

Hillers, A., M. Veith \& M. Rodel (2008). Effects of forest fragmentation and habitat degradation on West African Leaf-litter frogs. Conservation Biology 22: 762-772; http://dx.doi.org/10.1111/ j.1523-1739.2008.00920.x

Hill, G.E. (1995). Ornamental traits as indicators of environmental health. BioScience 45: 25-31.

Janzen, D. (1998). Gardenification of wildland nature and the human footprint. Science 279(5355): 1312-1313; http://dx.doi. org/10.1126/science.279.5355.1312

Kapoor, V. (2007). Effects of rainforest fragmentation and shade-coffee plantations on spider communities in the Western Ghats, India. Journal of Insect Conservation 12: 53-68; http://dx.doi.org/10.1007/ s10841-006-9062-5

Kuramoto, M., S.H. Joshy, A. Kurabayashi \& M. Sumida (2007). The genus Fejervarya (Anura: Ranidae) in central Western Ghats, India, with descriptions of four new cryptic species. Current Herpetology 26(2): 81-105; http://dx.doi.org/10.3105/18811019(2007)26[81:TGFARI]2.0.CO;2

Lips, K.R. (1998). Decline of a tropical montane amphibian fauna. Conservation Biology 12(1): 106-117; http://dx.doi.org/10.1111/ j.1523-1739.1998.96359.x

Menon, S. \& K.S. Bawa (1997). Applications of geographical information system, remote sensing and a landscape ecology approach to biodiversity conservation in Western Ghats. Current Science 73: 134-145.

Moguel, P. \& V.M. Toledo (1999). Review: biodiversity conservation in traditional coffee systems in Mexico. Conservation Biology 13 11-21; http://dx.doi.org/10.1046/j.1523-1739.1999.97153.x

Murcia, C. (1995). Edge effects in fragmented forests: implications for 
conservation. Trends in Ecology and Evolution 10: 58-62; http:// dx.doi.org/10.1016/S0169-5347(00)88977-6

Myers, N., R.A. Mittermier, C.G. Mittermier, G.A.B. da Fonseca \& J. Kent (2000). Biodiversity hotspots for conservation priorities. Nature 403: 853-858; http://dx.doi.org/10.1038/35002501

Neckel-Olivieira, S. \& C. Gascon (2006). Abundance, body size and movement patterns of a tropical tree frog in continuous and fragmented forests in the Brazilian Amazon. Biological Conservation 128(3): 308-315; http://dx.doi.org/10.1016/j.biocon.2005.09.037

Ninan, K.N. \& J. Sathyapalan (2005). The economics of biodiversity conservation: a study of a coffee growing region in the Western Ghats of India. Ecological Economics 55(1): 61-72; http://dx.doi. org/10.1016/j.ecolecon.2004.10.005

Noss, R.F (1990). Indicators for monitoring biodiversity. A hierarchical approach. Conservation Biology 4(4): 355-364; http://dx.doi. org/10.1111/j.1523-1739.1990.tb00309.x

Perfecto, I. (1995). Biodiversity and transformation of a tropical agrosystem: ants in coffee plantations. Ecological Application 5: 1084-1097.

Perfecto, I., R.A. Rice, R. Greenberg \& M. van der Voort (1996). Shade coffee: a disappearing refuge for biodiversity. Bioscience $46(8)$ 598-608.

Perfecto, I. \& J. Vandermeer (2002). Quality of agroecological matrix in a tropical montane landscape: ants in coffee plantations in southern Mexico. Conservation Biology 16(1): 174-182; http:// dx.doi.org/10.1046/j.1523-1739.2002.99536.x

Perfecto, I., M.A.T. Dietsch \& J. Vandermeer (2003). Conservation of biodiversity in coffee agro ecosystems: a tri-taxa comparison in southern Mexico. Biodiversity and Conservation 12(6): 1239-1252; http://dx.doi.org/10.1023/A:1023039921916

Pineda, E. \& G. Halffler (2004). Species diversity and habitat fragmentation: frogs in tropical montane landscape in Mexico. Biological Conservation 117(5): 499-508; http://dx.doi. org/10.1016/j.biocon.2003.08.009

Pineda, E., C. Moreno, F. Escobar \& G. Halffter (2005). Frog, bat and dung beetle diversity in cloud forest and coffee agro systems in Veracruz, Mexico. Conservation Biology 19(2): 400-410; http:// dx.doi.org/10.1111/j.1523-1739.2005.00531.x
Pogorzeiska, H., J. Knapowski \& M. Kontek (1982). Effects of certain pesticides on sodium transport in the epithelium of isolated frog skin. Acta Physiologica 33: 189-97.

Rappole, J.H., D.I. King \& J.H.V. Rivera (2003). Coffee and conservation Conservation Biology 17: 334-336.

Rice, R.A. \& R. Greenberg (2000). Cacao cultivation and the conservation of biological diversity. Ambio 29(3): 167-173; http:// dx.doi.org/10.1579/0044-7447-29.3.167

Rödel, M.O. \& R. Ernst (2004). Measuring and monitoring anuran diversity in tropical forests: an evaluation of methods with recommendation for standardization. Ecotropica 10: 1-14.

Schiesari, L., B. Grillitsch \& H. Grillitsch (2007). Biogeographical biases in research and their consequences for linking amphibian declines to pollution. Conservation Biology 21(2): 465-471; http://dx.doi. org/10.1111/j.1523-1739.2006.00616.x

SPSS. (2009). SPSS Base 18.0 for windows user's guide. SPSS, Chicago IL.

Turner, I.M. (1996). Species loss in fragments of tropical rain forest: a review of the evidence. Journal of Applied Ecology 33: 200-209.

Viswanath, R. (2003). From groves to temples. Down To Earth. http:// www.cseindia.org/dte-supplement/forest20031231/from_groves. htm. Downloaded on 1 August 2011.

Waltert, M., A. Mardiastuti \& M. Muhlenberg (2004). Effects of land use on bird species richness in Sulawesi, Indonesia. Conservation Biology 18(5): 1339-1346; http://dx.doi.org/10.1111/j.15231739.2004.00127.x

Welsh. H.H. \& L.M. Ollivier (1998). Stream amphibians as indicators of ecosystem stress: a case study from California's redwoods. Ecologica Applications 8: 1118-1132; http://dx.doi.org/10.1890/10510761(1998)008[1118:SAAIOE]2.0.CO;2

Zachariah, A., K.P. Dinesh, C. Radhakrishnan, E. Kunhikrishnan, M.J. Palot \& C.K. Vishnudas (2010). A new species of Polypedates Tschudi (Amphibia: Anura: Rhacophoridae) from southern Western Ghats, Kerala, India. Biosystematica 4: 55-59.

Zachariah, A., K.P. Dinesh, E. Kunhikrishnan, S. Das, D.V. Raju, C. Radhakrishnan, M.J. Palot \& S. Kalesh (2011). Nine new species of frogs of the genus Raorchestes (Amphibia: Anura: Rhacophoridae) from southern Western Ghats, India. Biosystematica 5: 25-48. 